\title{
Vegetative propagation of Acalypha hispida through cuttings with different types of media
}

\section{LM Rifnas ${ }^{1 *}$, NP Vidanapathirana ${ }^{1}$, TD Silva ${ }^{2}$, N Dahanayake ${ }^{3}, S$ Subasinghe ${ }^{3}$, SS Weerasinghe ${ }^{1}$,WGC Madushani ${ }^{1}$, SAP Nelka ${ }^{1}$ and H Rohanadheera ${ }^{1}$}

\author{
${ }^{1}$ Department of Agro Technology, Institute for Agro technology and Rural Sciences, Weligatta, Sri Lanka \\ ${ }^{2}$ Department of Plant Science, Faculty of Science, University of Colombo, Sri Lanka \\ ${ }^{3}$ Department of Agricultural Biology, Faculty of Agriculture, University of Ruhuna, Sri Lanka
}

Email: rifnaslm@yahoo.com

Received : 11.08.2021; Revised : 15.10.2021; Accepted : 19.10.2021

\begin{abstract}
Acalypha hispida is a wild flowering herbaceous plant commonly called as Red-hot cat's tail or Monkey tail, belongs to family Euphorbiaceae. It is commonly propagated by stem cuttings, but successful propagation of Acalypha hispida by stem cutting is harder, and even the basic information on these aspects are limited. Hence, an experiment was conducted to determine the effects of stem cutting types and growing media on the successful propagation of Acalypha hispida. Four types of stem cuttings (shoot tip, soft wood, semi hardwood and hardwood) and three types of media (pure sand, pure coir dust and 1:1 mixture of sand: coir dust v:v) were used, and the experiment was laid out in Complete Randomized Design (CRD) with $3 \times 4$ factor factorial arrangement. Data was analyzed by $S A S$ 9.1.3 software. It was observed that there was a significant $(P>0.05)$ interaction between the cutting types and media used in all the tested parameters except survival rate. All the type of cuttings planted in sand with coir dust showed highest percentage of rooted shoots with well formed root system. Hardwood cuttings planted in pure coir dust and 1:1 ratio of sand: coir dust showed not significant virtuous root weight (0.15g, $0.16 \mathrm{~g})$, number of leaves $(13.10,13.43)$, and shoot length $(3.53 \mathrm{~cm}, 3.34 \mathrm{~cm})$. Cutting types showed significant $(P>0.05)$ in survival and hardwood cuttings showed highest survival rate (80.56\%) compared to others. Accordingly, it could be concluded that hardwood cutting as the best material planted in a 1:1 mixture of sand with coir dust and pure coir dust medium can be used to propagate Acalypha hispida plants successfully.
\end{abstract}

Keywords: Acalypha hispida, media, propagation, rooting, stem cutting

\section{INTRODUCTION}

Acalypha hispida, the chenille plant, red hot cat's tail, monkey tail and fox tail are the names given around the world. It is a flowering shrub is a genus of the family Euphorbiaceae. It is mainly cultivated as an ornamental plant due to its attractiveness and brilliantly colored, furry flowers. Further, the leaves of the plants are laxative, diuretic in nature and used in the treatment of leprosy and gonorrhea. Various part of the plant is also used in infectious diarrhoea, pulmonary problems, and as an expectorant in asthma (Seebaluck et al., 2015). The leaves of Acalypha hispida has been reported to have cytotoxic, antibacterial (Bokshi et al., 2012) antileprotic (McLaughlin et al., 1998), antimicrobial (Adesina et al., 2000) and antifungal (Ejechi and Souzey, 1999) properties.

Stem cutting is the most common material used for vegetative propagation of many plant species from herbaceous to woody plants, including ornamental plants. The success of propagation via stem cuttings is often affected by many aspects, including the status of the mother plant, type of growing medium, nature of cutting, rooting hormones and environmental conditions. A better medium which can be used for plant propagation is consisted of factors that offer optimumporosity, drainage and moisture retention. The requirements for a propagation mediumare somewhat different from a potting medium, which may have to sustain a growing plant for a prolonged period of time. The role of a propagation medium is to give support and moisture while the plant is developing. Generally, in propagation, growers use different types of planting media such as peat, perlite, vermiculite, sand and various organic and inorganic composted materials to prepare nutritious mixtures for plant propagation. Coir dust is a by-products available in locally from coconut manufacturing processing units, and are used as a propagation and 
growing medium for propagation of several plants including medicinal plants such as Momordica dioica Roxb (Nawarathna et al., 2020), Salacia reticulata (Nayana et al., 2015), etc. for its better water holding capacity, higher contents of some nutrients such as potassium, sodium and magnesium (Abad et al.,2002).

Since there is lack of information available on propagation of Acalypha hispida plants, it is important to identify the proper successful and simple propagation technique for the efficient production of planting materials. Hence the present investigation was carried out with objectives of identification of most suitable planting material, growing media, and simple and effective protocol for in vivo propagation of Acalypha hispida plant.

\section{MATERIALS AND METHODS}

The study was conducted at the University of Colombo Institute for Agro-technology and Rural Sciences, Weligatta, Hambantota, Sri Lanka. The area falls under the low country dry zone agroecological region in Sri Lanka where the mean annual rain fall is $1250 \mathrm{~mm}-1500 \mathrm{~mm}$ and mean annual temperature ranging between $29^{\circ} \mathrm{C}-33^{\circ} \mathrm{C}$. Common soil type representing area is reddish brown earth. Three types of growing media (pure coir dust, pure sand, 1:1 mixture of sand and coir dust parts by volume) and four types of stem sectionsas hardwood (fully matured brownish and woody parts), semi hardwood (partially matured and slightly woody), softwood (made up of soft and succulent parts just below the shoot tip) and shoot tips (topmost three nodes with shoot tip) were used for the experiment. The experiment was laid out in the Complete Randomized Design with factorial arrangement having twelve treatments and four replications. Each replication contained three experimental units.

A pest free, healthy mother plant was selected nearby the experimental area for collection of planting materials. Required amount of stem cuttings were collected from a single mother plant. Healthy branches of Acalypha hispida were detached from mother plant early in the morning and adaxial ends were dipped in water to prevent from drying and avoiding trapping of air bubble in vascular system until transport to the experimental area.

Pure sand and coir dust were sieved to remove unwanted materials and to get fine particles to facilitate rooting. Pots of $10 \mathrm{~cm} \times 15 \mathrm{~cm}$ were prepared with black polyethylene and holes at the bottom to facilitate the drainage of excess water.The pots were filled with the potting mixtures and treated with a fungicide to sterilize the media. Nodal cuttings with different maturity stages were separated using sharp knife to prevent the tissue damages. A slant cut was made at the adaxial end of the each cutting just below the node to increase the surface area. The cut surface was garnished with a rooting hormone containing $0.03 \%$ Indole Butyric Acid to promote the rooting. Each cutting was carefully planted in polyethylene pots inserting at least a node completely to be inside the media.

Planted cuttings were maintained under completely sealed propagator covered using 500 gauge transparent polyethylene sheet. The structure was maintained under $50 \%$ shade condition throughout four weeks of time. Watering was not practiced during the period under propagator. After four weeks, cuttings were taken out from propagator and survival percentage, percentage of rooted cuttings, number of leaves, number of new shoots, shoot length, root number and root weight were measured.

The recorded data were statistically analyzed using PROC GLM procedures in SAS 9.1.3 statistical software. The difference between the treatments means were compared using Duncan Multiple Range Test (DMRT) at 5\% significant level.

\section{RESULTS AND DISCUSSION}

\section{Effect of cutting type and potting media on survival}

There was no significant $(\mathrm{p}<0.05)$ interaction between the tested factors on survival of Acalypha hispida plants. Stem cutting types showed highly significant $(\mathrm{P}>0.05)$ effect on percentage survival. As shown in Table 1, among the four types of stem cutting, hardwood showed highest $(80.60 \%)$ survival followed by semi hardwood, softwood and shoot tip with $55.60 \%, 38.90 \%$ and $19.40 \%$ respectively. The results suggested that matured 
Table 1: Effects of cutting type and media on survival rate of Acalypha hispida

\begin{tabular}{|c|c|c|}
\hline \multicolumn{2}{|c|}{ Treatments } & \multirow{2}{*}{$\frac{\text { survival rate }}{39.50^{\mathrm{a}}}$} \\
\hline Media types & Sand & \\
\hline & Coir dust & $47.80^{\mathrm{a}}$ \\
\hline & Sand + Coir dust & $58.50^{\mathrm{a}}$ \\
\hline & Significant & NS \\
\hline \multirow[t]{5}{*}{ Cutting types } & Shoot tip & $19.40^{\mathrm{c}}$ \\
\hline & Softwood & $38.90^{\mathrm{bc}}$ \\
\hline & Semi hardwood & $55.60^{\mathrm{b}}$ \\
\hline & Hardwood & $80.60^{\mathrm{a}}$ \\
\hline & Significant & $*$ \\
\hline
\end{tabular}

Means followed by the different superscripts in a same column are significantly different at DMRT 5\%. * Represents significant at 5\% and ns represents not significant.

stem cutting of Acalypha hispida has been reliable in survival possibly due to the content of adequate food reserves which feed cuttings until it forms roots. This results were in agreement with observations on previous studies, where cuttings with larger diameter and longer length showed better survival rate and growth under normal conditions (Vigl and Rewald, 2014 on Salicaceae; Ouyang et al., 2015). Furthermore, a study on cutting propagation of Hevea brasiliensis by Corpuz (2013) proved that, there was a significantly higher survival rate found in brown cut stem (hardwood) than green cut stems (softwood).

\section{Effect of cutting type and potting media on percentage of rooted shoots}

There was a significant $(p>0.05)$ interaction between stem cutting type and media on rooting of Acalypha hispida (Table 2). All the types of stem cuttings planted on 1:1 sand: coir dust showed highest rooting percentage $(100 \%)$ compared to others. Those were not significantly different with hardwood and shoot tip cuttings planted in pure sand and pure coir dust. Soft wood cutting planted in pure sand showed lowest performance in rooting (Table 2). This results indicated that the growing medium is the most influencing factor on rooting. Sand with coir dust enhanced the rooting ability of all the type of cuttings. These results were in agreement with the findings of Lokesha et al. (1988). It is reported that higher percentage of rooting in Acalypha was found in coir dust when compared to sand. Studies on Bougainvillea by Singh et al. (2020) showed that, the hardwood cuttingsplanted in different growing media were found significantly better than the control with respect to rooting of cuttings.

A study on propagation of Ricinodendronheudelotti Baill cuttings belongs to family Euphorbiacae by Tchinda et al. (2013) showed that, cutting type had significant effects on individual rooting of the accession and it is responsible for almost $70 \%$ of obtained results for rooting rate, leaf number and root length. Further, they mentioned that, rooting is generally depending on potting media, cutting type, pre-treatment and harvesting time.

\section{Effect of cutting type and potting media on root weight}

As shown in Table 2, significant $(\mathrm{p}>0.05)$ interaction was found between the cutting type and media on root weight. There was no significant root weights were found where hardwood cuttings planted in sand: coir dust $(0.16 \mathrm{~g})$ and pure coir dust $(0.15 \mathrm{~g})$. Lowest performances were found in all the types of cuttings planted in pure sand. The hardwood cuttings showed better performance in root weight possibly due to its effectiveness and availability of reserved materials for growth of root.

As indicated by Ramtin et al. (2011), a study on Poinsettia pulcherrima L. proved that the type of cutting had a great effect on the rooting of Poinsettia and lower cutting (hardwood cutting) was identified as the most suitable for rooting. Higher food reserves in the hardwood cuttings enhanced the root development.The results obtained in this experiment may be due to coir dust 
and sand when combine together itpromotes faster root growth and gave quicker anchorage to young roots. This mixture may help in retaining air, plant food and moisture and releasing them as when the plant requires. Influence of medium is felt before rooting occurs due to water retention and aeration properties which ultimately increase percentage, length and quality of roots (Fagge and Manga, 2011).

\section{Effect of cutting type and potting media on number of leaves}

The stem cutting and media showed significant $(\mathrm{P}>0.05)$ interaction on average number of leaves produced (Table 2). Hardwood cutting planted in 1: 1 ratio of sand, coir dust and pure coir dust have produced highest average number of leaves (13.43, 13.10). Lowest number of leaves (1) obtained in shoot tip cuttings planted in pure coir dust.An experiment on Zinnia elegans by Riaz et al. (2008) mentioned that, in general, mixture of silt + leaf manure + coconut compost $(1: 1: 1)$ gave the highest values of growth parameter such as number of leaves per plant. Further indicated by Dewayne et al. (2003) both physical and chemical characteristics of the growth medium exert substantial effect on growth of plants. Physical characteristics of aeration and water holding capacity are probably the most important factors while, the chemical characteristics such as nutritional status, and salinity level have a crucial role on plant development (Dewayne et al., 2003).

Table 2: Interaction effects of cutting type and media on percentage of shoot produced roots, number of leaves, shoot length and root weight

\begin{tabular}{|c|c|c|c|c|c|}
\hline Media types (M) & $\begin{array}{l}\text { Cutting types } \\
\text { (C) }\end{array}$ & $\begin{array}{c}\text { \%o of shoot } \\
\text { produced roots }\end{array}$ & $\begin{array}{c}\text { Root weight } \\
\text { (g) }\end{array}$ & $\begin{array}{l}\text { No. of } \\
\text { leaves }\end{array}$ & $\begin{array}{c}\text { Shoot } \\
\text { length }(\mathrm{cm})\end{array}$ \\
\hline \multirow[t]{4}{*}{ Sand } & Tip & $100^{\mathrm{a}}$ & $0.03^{\text {ef }}$ & $2^{\mathrm{de}}$ & $0.36^{\text {ef }}$ \\
\hline & Softwood & $0^{\mathrm{d}}$ & $0^{\mathrm{f}}$ & $2^{\text {de }}$ & $0.08^{f}$ \\
\hline & Semihardwood & $16.67^{\mathrm{c}}$ & $0.05^{\mathrm{f}}$ & $2.75^{\mathrm{de}}$ & $0.43^{\text {ef }}$ \\
\hline & Hardwood & $100^{\mathrm{a}}$ & $0.01^{\mathrm{f}}$ & $8.75^{b}$ & $1.20^{\mathrm{de}}$ \\
\hline \multirow[t]{4}{*}{ Coir dust } & Tip & $100^{\mathrm{a}}$ & $0.02^{\mathrm{ef}}$ & $1^{\mathrm{e}}$ & $0.30^{\mathrm{f}}$ \\
\hline & Softwood & $75^{\mathrm{ab}}$ & $0.08^{\mathrm{bcd}}$ & $5.48^{c}$ & $1.20^{\mathrm{de}}$ \\
\hline & Semihardwood & $50^{\mathrm{bc}}$ & $0.05^{\mathrm{de}}$ & $5.65^{\mathrm{c}}$ & $1.54^{\mathrm{cd}}$ \\
\hline & Hardwood & $100^{\mathrm{a}}$ & $0.15^{\mathrm{a}}$ & $13.10^{\mathrm{a}}$ & $3.53^{\mathrm{a}}$ \\
\hline \multirow[t]{4}{*}{ Sand + Coir dust } & Tip & $100^{\mathrm{a}}$ & $0.09^{\mathrm{bc}}$ & $3^{\mathrm{d}}$ & $0.16^{\mathrm{f}}$ \\
\hline & Softwood & $100^{\mathrm{a}}$ & $0.05^{\text {cde }}$ & $5.38^{c}$ & $2.16^{\mathrm{bc}}$ \\
\hline & Semihardwood & $100^{\mathrm{a}}$ & $0.12^{\mathrm{b}}$ & $8.30^{\mathrm{b}}$ & $2.40^{\mathrm{b}}$ \\
\hline & Hardwood & $100^{\mathrm{a}}$ & $0.16^{\mathrm{a}}$ & $13.43^{\mathrm{a}}$ & $3.34^{\mathrm{a}}$ \\
\hline \multirow[t]{3}{*}{ Significant } & $\mathrm{M} \times \mathrm{C}$ & * & * & * & * \\
\hline & $\mathrm{M}$ & $*$ & $*$ & $*$ & $*$ \\
\hline & $\mathrm{C}$ & $*$ & $*$ & $*$ & $*$ \\
\hline
\end{tabular}

Means followed by the different superscripts in a same column are significantly different at DMRT $5 \%$. ${ }^{*}$ Represents significant at $5 \%$ and ns represents not significant.

\section{Effect of cutting type and potting media on shoot length}

There was a significant $(p>0.05)$ interaction between the factors tested on length of the shoot. Hardwood cuttings planted in pure coir dust and 1:1 sand: coir dust obtained the longest shoot length (Table 2) with $3.53 \mathrm{~cm}, 3.34 \mathrm{~cm}$, respectively. Lowest shoot length $(0.08 \mathrm{~cm})$ was found where softwood cutting planted in pure sand. The hardwood cuttings of Acalypha hispida showed better growth, possibly due to higher reserves in the tissues. Hardwood part of the stem consists of materials necessary for stem growth including nucleic acids, proteins and natural hormones among them, Indole acetic acid which exists in all kinds of plants. It was reported that coir dust possesses good water holding capacity and releases phenolic compounds which promote shoot initiation and better performances of cuttings (Lokesha et al., 1988; Smith, 1955). 
Coir dust mixed with potting media helps in maintaining the appropriate texture of the growing media and prevents compaction, thereby resulting in better root growth and shoot growth (Fagge and Manga, 2011). A study on Antidesma bunius, belongs to family Euphorbiacae, by Totaan (2019) is on par with the results of Acalypha hispida. The study showed that basal section of the stem cuttings (hardwood type of cutting) obtained highest shoot length followed by middle section (semi hardwood). The basal section of Antidesma bunius stem cuttings has thicker and larger diameter as compared to the apical and middle portion that could probably produce the longer shoot length.

\section{CONCLUSIONS}

The present study showed that there was significant variability in shoot and root development of the cutting type with media. Hardwood cuttings planted in the media contained sand mixed with coir dust at the ratio of 1:1 and pure coir dust media showed the significantly highest performances in most tested parameters. Therefore, Acalypha hispida plants steadily be propagated with highest survival rate and rooting percentage using hardwood cuttings planted in sand: coir dust 1:1 mixture or pure coir dust media.

\section{ACKNOWLEDGEMENT}

This research was supported by the Accelerating Higher Education Expansion and Development (AHEAD) Operation of the Ministry of Higher Education funded by the World Bank.

\section{REFERENCES :}

Abad, M., Noguera, P., Puchades, R., Maquieira, A. and Noguera, V. 2002. Physico-chemical and chemical properties of some coconut coir dusts for use as a peat substitute for containerized ornamental plants. Bioresource technology, 82: 241-245.

Adesina, S.K., Idowu, O., Ogundaini, A.O., Oladimeji, H., Olugbade, T.A., Onawunmi, G.O. and Pais, M. 2000. Antimicrobial constituents of the leaves of Acalypha wilkesiana and Acalypha hispida. Phytotherapy Research, 14 (5):371-374.

Bokshi, B., Sayeed, M.A.S., Ahmed, M.I., Karmakar, U.K. and Sadhu, S.K. 2012. Assessment of antimicrobial and cytotoxic activities of ethanolic extract of leaves of Acalypha hispida. International Journal of Pharmaceutical Sciences and Research, 3(6): 1705.

Corpuz, O.S. 2013. Stem cut: An alternative propagation technology for rubber (Hevea brasiliensis) tree species. International journal of biodiversity and conservation, 5(2):78-87.

Dewayne, L.I., Richard, W.H. and Thomas, H.Y. 2003. Growth Media for Container Grown Ornamental Plants. The Environmental Horticulture Department, Florida Cooperative Extension Service, Institute of Food and Agricultural Sciences, University of Florida, BUL241.

Ejechi, B.O. and Souzey, J.A. 1999. Inhibition of biodeterioration of yam tuber Dioscorea rotundata Poir in storage with phenolic extract of Acalypha hispida Burm. f. leaves. Journal of Stored Products Research, 35(2):127-134.

Fagge, A.A. and Manga, A.A. 2011. Effect of sowing media and gibberellic acid on the growth and seedling establishment of Bougainvillea glabra, Ixora coccinea and Rosa chinensis. 2. Root Characters. Bayero Journal of Pure and Applied Sciences, 4(2):155-159.

Lokesha, R., Mahish, D.M. and Shivashankar, G. 1988. Studies on use of coconut coir dust as a rooting media. Current Research.University of Agr. Sci. Bangalore, 17:157-158.

McLaughlin, J.L., Rogers, L.L. and Anderson, J.E. 1998. The use of biological assays to evaluate botanicals. Drug information journal, 32(2):513-524.

Nawarathna, S.L., Subasinghe, S., Vidanapathirana, N.P. and Kumarasinghe, H.K.K.S. 2020. Impact of potting medium and cutting types on rooting and survival performance of male plants of Momordica dioica. Roxb (Thumba Karawila). International Journal of Minor Fruits, Medicinal and Aromatic Plants, 6(2):2-79.

Nayana, E.K.E., Subasinghe, S., Amarasinghe, M.K.T.K., Arunakumara, K.K.I.U. and Kumarasinghe, H.K.M.S. 2015. Effect of maturity and potting media on vegetative 
propagation of Salacia reticulata (Kothalahimbatu) through stem cuttings. International Journal of Minor Fruits, Medicinal and Aromatic Plants, 1(1):47-54.

Ouyang, F., Wang, J. and Li, Y. 2015. Effects of cutting size and exogenous hormone treatment on rooting of shoot cuttings in Norway spruce [Piceaabies (L.) Karst.]. New forests, 46:91-105.

Ramtin, A., Khalighi, A., Hadavi, E. and Hekamati, J. 2011. Effect of different IBA concentrations and types of cuttings on rooting and flowering Poinsettia pulcherrima L. Intl J Agri Sci, 1: 303-310.

Riaz, A., Arshad, M., Younis, A., Raza, A. and Hameed, M. 2008. Effects of different growing media on growth and flowering of Zinnia elegans cv. Blue point. Pak. J. Bot, 40(4):1579-1585.

Seebaluck, R., Gurib-Fakim, A. and Mahomoodally, F. 2015. Medicinal plants from the genus Acalypha (Euphorbiaceae)A review of their ethno pharmacology and phytochemistry. Journal of ethnopharmacology, 159 : 137-157.
Singh, B., Sindhu, S.S., Harendra, Y. and Saxena, N.K. 2020. Effect of different potting media on Bougainvillea propagation cv. Mahara. Chem Sci Rev Lett,9 (33):158-161.

Smith, C.H. 1995. Coir: a viable alternative to peat for potting. The Horticulturist, 4(3):12-25.

Tchinda, N.D., Messi, H.J.C.M., Nzweundji, G., Tsabang, N., Dongmo, B., Oumar, D., Tarkang, P.A., Caver, A. and Ndoumou, D.O. 2013. Improving propagation methods of RicinodendronheudelottiBaill. from cuttings. South African Journal of Botany, 88:3-9.

Totaan, D. 2019. Effects of stem cutting section and Indole-3-Butyric Acid on the vegetative propagation of Antidesma Bunius (Linn) Spreng. Available at SSRN 3464989.

Vigl, F. and Rewald, B. 2014. Size matters?-The diverging influence of cutting length on growth and allometry of two Salicaceae clones. Biomass and Bioenergy, 60:130-136. 